\title{
Active Biopolymeric Films Inoculated with Bdellovibrio bacteriovorus, a Predatory Bacterium
}

\author{
Christian Mariel Sáenz-Santos ${ }^{1}$ D , Omotayo Opemipo Oyedara ${ }^{2}$ D , Yunia Verónica García-Tejeda ${ }^{3, *(D)}$, \\ Claudia A. Romero-Bastida ${ }^{4}$, Esperanza Milagros García-Oropesa ${ }^{5}$ and Eduardo Villalobo ${ }^{6}$ and \\ Mario A. Rodríguez-Pérez ${ }^{1, * \mathbb{D}}$
}

1 Instituto Politécnico Nacional, CBG, Blvd. del Maestro esquina Elías Piña, Col. Narciso Mendoza, Reynosa 88710, Mexico; csaenzs1600@alumno.ipn.mx

2 Department of Microbiology, Osun State University, Osogbo Campus, Osogbo P.M.B. 4494, Nigeria; omotayo.oyedara@uniosun.edu.ng

3 Instituto Politécnico Nacional, UPIITA, Academia de Ciencias Básicas, Av. Instituto Politécnico Nacional No. 2580, Col. Barrio la Laguna Ticomán, Gustavo A. Madero, Mexico City 07340, Mexico

4 Instituto Politécnico Nacional, CEPROBI, Carretera Yautepec Jojutla, Km. 6, Calle CeProBi No. 8, Col. San Isidro, Yautepec 62731, Mexico; cbastida@ipn.mx

5 Universidad Autónoma de Tamaulipas, Unidad Académica Multidisciplinaria, Reynosa Aztlán, Laboratorio de Biología Molecular, Mariano Matamoros S/N, Zona Centro, Victoria 87000, Mexico; egoropesa@uat.edu.mx

6 Facultad de Biología, Universidad de Sevilla, Av. de la Reina Mercedes, 41012 Sevilla, Spain; evpolo@us.es

* Correspondence: ygarciat@ipn.mx (Y.V.G.-T.); drmarodriguez@hotmail.com (M.A.R.-P.)

Citation: Sáenz-Santos, C.M.; Opemipo Oyedara, O.; García-Tejeda, Y.V.; Romero-Bastida, C.A.; García-Oropesa, E.M.; Villalobo, E.; Rodríguez-Pérez, M.A. Active Biopolymeric Films Inoculated with Bdellovibrio bacteriovorus, a Predatory Bacterium. Coatings 2021, 11, 605. https://doi.org/10.3390/ coatings11050605

Academic Editor: Junsang Ham

Received: 4 April 2021

Accepted: 14 May 2021

Published: 20 May 2021

Publisher's Note: MDPI stays neutral with regard to jurisdictional claims in published maps and institutional affiliations.

Copyright: (c) 2021 by the authors. Licensee MDPI, Basel, Switzerland. This article is an open access article distributed under the terms and conditions of the Creative Commons Attribution (CC BY) license (https:/ / creativecommons.org/licenses/by/ $4.0 /)$.
Abstract: The objective of the present work was to evaluate novel active films made with biopolymeric matrices as carriers of a living Bdellovibrio bacteriovorus HD100 strain, a predatory bacterium with antimicrobial potentials against pathogens. Biopolymer films were prepared by a casting method using the following mixtures: collagen/sodium alginate/sorbitol (CA-S), collagen/sodium alginate/glycerol (CA-G), and tapioca starch/sodium alginate/glycerol (StA-G). The effects of the film formulations on the viability of the B. bacteriovorus was investigated by using Fourier Transform Infrared (FTIR) spectroscopy, Differential Scanning Calorimetry (DSC), and Scanning Electron Microscopy (SEM). SEM showed that Bdellovibrio bacteriovorus morphology was not altered in the polymeric films. FTIR spectroscopy provided information about the structural composition of the films. CA-S showed less reduction in the viability of B. bacteriovorus after its entrapment; thus, CA-S proved to be a better agent for the immobilization and preservation of B. bacteriovorus to enhance its predatory activities during application against Escherichia coli.

Keywords: active film; Bdellovibrio entrapment; collagen; sodium alginate; starch

\section{Introduction}

In recent years, active packagings for increasing the shelf life of foods has attracted much attention in the field of food preservation due to increased demand for foods that are free of synthetic preservatives [1,2]. Biological control of bacterial pathogens using Bdellovibrio bacteriovorus (B. bacteriovorus) and other bacteria [3] is a new alternative to preservatives, considering that synthetic chemical preservatives and additives should be avoided because many of these could cause health damage [4].

$B$. bacteriovorus is a deltaproteobacterium that preys especially upon other Gramnegative bacteria. $B$. bacteriovorus invade the periplasm of their prey, forming a structure called a bdelloplast [5]. Within the bdelloplast, B. bacteriovorus grows, multiplies, and finally lyses its prey, releasing progenies that can continue the attack [6]. As a prokaryotic predator, B. bacteriovorus has the potential to serve as an agent for the biocontrol of bacterial pathogens. Additionally, it is safe for humans as a therapeutic agent and found in abundance in healthy 
human beings [7,8]; however, for the effective use of B. bacteriovorus as a biocontrol agent in food packaging, it is paramount to keep it viable and stable.

The selection and development of a suitable encapsulating agent are important for the viability of $B$. bacteriovorus. Moreover, encapsulating agents of natural polymer origin can serve as adjuvants for the protection and stability of B. bacteriovorus when applied to control pathogens during food storage. The sources of natural polymers used for edible packaging films include gums (e.g., arabic, xanthan, gellan, and curdlan), plants (e.g., starch, cellulose, pectin, and gum acacia), animals (e.g., whey protein, collagen, keratin, and gelatin), algae (e.g., alginate and carrageenan), and fungi (e.g., chitin, pullulan, and scleroglucan).

In this study, the viability of B. bacteriovorus was tested in three of the natural polymers, and these include collagen, alginate, and starch. Collagen is a long and fibrous protein, which constitutes approximately $30 \%$ of the body's total protein mass in mammals. Collagen fibrils are present in tendons, skin, bones, cornea, ligaments, muscle, and dentin [9]. Various authors have reported collagen films derived from various sources, including bovine [10], cow [11], and fish skins [12]. Furthermore, collagen films have wide applications because of their good flexibility and strong mechanical properties due to the self-aggregation and crosslinking of collagen fibrils [10]. Sodium alginate is a natural polysaccharide derived from brown algae, which when combined with collagen, forms films with suitable mechanical and barrier properties [13]. Sodium alginate has application in food packaging industries. Starch is a natural polymer of plant origin that has found its application in the food industries. For instance, L. acidophilus has been successfully encapsulated in cassava starch edible films [14]. In anticipation of finding alternative preservation methods to combat the proliferation of food spoilage and pathogenic bacteria, $B$. bacteriovorus, a predatory bacterium, has been recently considered as a biocontrol agent.

To the best of our knowledge, there has been no report on the use of biopolymeric films for immobilization of B. bacteriovorus. This work is focused on the production of active biopolymeric films, and the paper is aimed at: (1) trapping the B. bacteriovorus HD100 strain using the following mixtures: collagen/sodium alginate/sorbitol (CA-S), collagen/sodium alginate/glycerol (CA-G), and tapioca starch/sodium alginate/glycerol (StA-G); (2) determining the entrapment yield of the B. bacteriovorus HD100 strain in these formulations; and (3) characterizing the mechanical and thermal properties of biopolymeric films.

\section{Materials and Methods}

\subsection{Biopolymers, Media, and Bacterial Strains}

Sodium alginate and hydrolysed collagen were acquired from D'xilou (Mexico city, Mexico). Tapioca starch was acquired from Bob's Red Mill Natural Foods (Milwaukie, OR, USA).Sorbitol, glycerol and all media were acquired from Sigma-Aldrich ${ }^{\circledR}$ (St. Louis, MO, USA). Bdellovibrio bacteriovorus HD100 strain and Escherichia coli DH5 $\alpha$ were provided by the CBG-IPN (Reynosa Tamps, Mexico).

\subsection{Inoculum Preparation}

The host bacteria, E. coli DH5 $\alpha$, was cultured in $40 \mathrm{~mL}$ of LB broth at $37^{\circ} \mathrm{C}$ under agitation for the duration of a night. After that, the E. coli culture was centrifuged at $3000 \mathrm{rpm}$ and the pellet was washed with $10 \mathrm{~mL}$ of HEPES buffer containing $3 \mathrm{mmol} / \mathrm{L}$ of $\mathrm{CaCl}_{2} \cdot 2 \mathrm{H}_{2} \mathrm{O}$ and $2 \mathrm{mmol} / \mathrm{L}$ of $\mathrm{MgCl}_{2} \cdot 6 \mathrm{H}_{2} \mathrm{O}$ (pH 7.4). The predatory bacteria of the B. bacteriovorus HD100 strain were cultured in the presence of the host bacteria on DNB agar using the double agar overlay method [15]. After that, a lytic plaque was obtained and purified by repeating the double agar overlay method.

The purified plaque was inoculated with $50 \mathrm{~mL}$ of $E$. coli contained in HEPES buffer and after predatory activity, $40 \mathrm{~mL}$ of the cleared lysate were filtered (MF-Millipore ${ }^{\mathrm{TM}}$ of $0.45 \mu \mathrm{m}$ ) in order to purify B. bacteriovorus. Purified B. bacteriovorus cells in co-culture with washed $E$. coli cells were incubated at $30^{\circ} \mathrm{C}$ under agitation for $7 \mathrm{~d}$. B. bacteriovorus was purified again, and was concentrated by centrifugation $(15,700 \mathrm{rpm})$ and washed 
twice with $50 \mathrm{~mL}$ of phosphate-buffered saline. The resulting concentration contained $1 \times 10^{8} \mathrm{PFU} / \mathrm{mL}$ of B. bacteriovorus cells, which were used to inoculate biopolymeric films.

\subsection{B. bacteriovorus Entrapment in Biopolymeric Films}

Inoculation of $B$. bacteriovorus in the films was carried out by the casting method; three different biopolymeric films were prepared. Biopolymeric films were prepared by the casting method using two plasticizers and combined polymers: a collagen-sodium alginate film plasticized with sorbitol (CA-S), a collagen-sodium alginate film plasticized with glycerol (CA-G), and a tapioca starch-sodium alginate film plasticized with glycerol (StA-G).

For CA-S, $25 \mathrm{~g}$ of hydrolyzed collagen, $2.5 \mathrm{~g}$ of sodium alginate, $17.5 \mathrm{~g}$ of sorbitol, and $230 \mathrm{~mL}$ of distilled water were used. For CA-G, $25 \mathrm{~g}$ of hydrolyzed collagen, $2.5 \mathrm{~g}$ of sodium alginate, $10 \mathrm{~g}$ of glycerol as a plasticizer, and $230 \mathrm{~mL}$ of tap water were used. For StA-G, $8.75 \mathrm{~g}$ of tapioca starch, $3.75 \mathrm{~g}$ sodium alginate, $10 \mathrm{~g}$ of glycerol as a plasticizer and $230 \mathrm{~mL}$ of distilled water were used. The amounts chosen for starch formulation were based on the results reported in [13].

All of the prepared mixtures were homogenized by mechanical stirring at $110^{\circ} \mathrm{C}$ for $20 \mathrm{~min}$ and later sterilized in an autoclave for $15 \mathrm{~min}$ at $121^{\circ} \mathrm{C}$. The films were obtained by casting the suspension into Teflon moulds $\left(11 \times 21.5 \mathrm{~cm}^{2}\right)$. The filmogenic solution $(10 \mathrm{~mL})$ at $40{ }^{\circ} \mathrm{C}$ was poured into a Teflon mold, and subsequently a concentrated pellet of the $B$. bacteriovorus HD100 strain $\left(1 \times 10^{8} \mathrm{PFU} / \mathrm{mL}\right)$ was added to the solution. The film was dried out in a ventilated oven at $37^{\circ} \mathrm{C}$ overnight. The thin biofilms were removed from the molds and stored in desiccators until their use.

\subsubsection{Scanning Electron Microscopy (SEM)}

Bacteria trapped within the polymeric matrices were observed in a Dual-Beam SEM FEI Nova 200 (Nova NanoLab ${ }^{\mathrm{TM}}$, Tustin, CA, USA), using a low acceleration voltage of 3-5 $\mathrm{kV}$ and a chamber pressure of 0.60 mbar. The active biopolymeric films were fixed on aluminum stubs with double-faced adhesive tape. Magnifications at $1500 \times, 5000 \times$, and $10,000 \times$ were obtained by image analysis.

\subsubsection{Evaluation of the Entrapment Yield of B. bacteriovorus in the Biopolymeric Films}

The viability of the predatory bacteria was quantified after drying the films by measuring the number of plaque-forming units produced. Dry films loaded with B. bacteriovorus HD100 were rehydrated in $5 \mathrm{~mL}$ of sterile distilled water for $10 \mathrm{~min}$ and were serially diluted ten-fold. The diluted film solution was cultured on dilute nutrient broth agar medium (DNB) using the double-layered agar plating technique and E. coli DH5 $\alpha$ as prey. The number of plaques that developed after $72 \mathrm{~h}$ from the rehydrated filmogenic solution was recorded and expressed in PFU $/ \mathrm{mL}$. The entrapment yield (EY) of biopolymeric films was calculated as follows:

$$
\operatorname{EY}(\%)=\frac{N}{N_{0}} \times 100,
$$

where $N_{0}$ is the inoculum concentration in PFU/g of the film and $N(\mathrm{PFU} / \mathrm{g}$ ) is the viable cells' concentration extracted from the films after employing the casting method. The total count of the viable cells was analyzed in triplicate. The statistical analysis was carried out using the Mann-Whitney $U$ test $(p<0.01)$ by using SigmaPlot 14.5 software (SYSTAT, San Jose, CA, USA).

\subsubsection{Lytic Activity of B. bacteriovorus HD100 against E. coli DH5 $\alpha$ in Co-Culture Assay}

The predatory activity of Bdellovibrio bacteriovorus HD100 to reduce the concentration of Escherichia coli DH5 $\alpha$ in the co-culture was assessed after 24 and $48 \mathrm{~h}$. The reduction of E. coli was determinate by $\mathrm{CFU} / \mathrm{mL}$ count as follows: serial dilutions $\left(10^{2}\right.$ to $\left.10^{9}\right)$ were prepared from one milliliter aliquot collected from the co-culture (Section 2.2) after 24 and $48 \mathrm{~h}$. Subsequently, $100 \mu \mathrm{L}$ of each dilution were spread-plated onto LB agar to determine the $\mathrm{CFU} / \mathrm{mL}$ of the respective prey cell cultures. In addition, the double-layered agar plating 
technique was used to count the PFU/mL of B. bacteriovorus HD100. The measurements were performed in triplicate.

Lytic activity of predatory bacteria was observed in the form of clear areas in plaques containing a lawn of prey cells; photographs were captured by using a smartphone camera.

\subsection{Physicochemical Properties of Biofilms}

\subsubsection{Fourier Transform Infrared Spectroscopy (FTIR)}

Molecular interactions in biopolymeric films were studied by FTIR spectroscopy using a Jobin-Yvon LabRam HR800 spectrometer (HORIBA Scientific, Piscataway, NJ, USA). The individual polymers and biofilms were analyzed over the range of $4000-4500 \mathrm{~cm}^{-1}$, with $4 \mathrm{~cm}^{-1}$ of spectral resolution and 40 scans per sample, using an attenuated total reflectance objective.

\subsubsection{X-ray Diffraction (XRD) Analysis of the Biopolymeric Films}

The XRD analysis of biopolymeric films was determined on a Rigaku Miniflex 600 diffractometer (Rigaku ${ }^{\circledR}$, Tokyo, Japan). The instrument was operated at $40 \mathrm{kV}$ and $15 \mathrm{~mA}$ with $\mathrm{CuK} \alpha$ radiation $(\lambda=1.54 \AA)$ in $2 \theta$ sweeping from $0^{\circ}$ to $60^{\circ}$ with a step size of 0.01 and $0.03 \% \mathrm{~min}$. The degree of crystallinity $(\% \mathrm{Cr})$ was determined according to the method described in [16]. OriginPro 10 software (OriginLab Corporation, Northampton, MA, USA) was used to analyze the spectrum.

\subsubsection{Thermal Analysis by Differential Scanning Calorimetry (DSC)}

The melting temperature $\left(T_{p}\right)$, the melting enthalpy $(\Delta H) \mathrm{in} \mathrm{J/g}$, and the glass transition $\left(T_{g}\right)$ temperature of casting films, as well as the $T_{g}$ and $\Delta C_{p}$ of film-forming polymers, were determined using a Discovery DSC calorimeter (TA Instruments, New Castle, DE, USA) calibrated with indium [17]. Samples of approximately $2.1 \mathrm{mg}$ were weighed into Tzero ${ }^{\circledR}$ Hermetic Aluminum pans, and after that the samples were subjected to a cooling program from 25 to $-75^{\circ} \mathrm{C}$ and to a heating program from -75 to $170{ }^{\circ} \mathrm{C}\left(10^{\circ} \mathrm{C} / \mathrm{min}\right)$. The analysis was performed in triplicate using the software TRIOS 5.1.1 (TA Instruments, New Castle, DE, USA).

\subsubsection{Mechanical Analysis of the Biopolymeric Films}

The biopolymeric films were stored in a desiccator at $57 \%$ relative humidity for $72 \mathrm{~h}$ before analysis. Subsequently, the samples were cut at dimensions of $100 \times 10 \mathrm{~mm}$ (ASTM D882-02 method). The tensile strength (MPa), the elongation at break (\%), and the Young's modulus (Mpa) were determined using a TA.TX2i texture analyzer (Stable Micro Systems, Surrey, UK) following the methodology of a previous work [18]. The analysis was performed by tenfold.

\section{Results and discussion}

\subsection{Molecular Interactions}

Figure 1 shows FTIR spectra of the individual polymers. Tapioca starch exhibited absorption band characteristics at the band of $3692-3000 \mathrm{~cm}^{-1}$, where the maximum absorption was found at $3300 \mathrm{~cm}^{-1}$; this band is associated with the tensile stress of the vibrational free bonds of inter- and intramolecular hydroxyl groups of the anhydroglucose units. The peaks observed at 2923,1411, and $1350 \mathrm{~cm}^{-1}$ are attributed to $\mathrm{CH}$ stretching vibrations and bending between methylene groups [19]. The peak at $1635 \mathrm{~cm}^{-1}$ is associated with the bending vibration of $\mathrm{H}_{2} \mathrm{O}$ and $\mathrm{H}-\mathrm{O}-\mathrm{H}$, which presumably originates from tightly bound water present in the starch granules $[20,21]$. Three characteristic peaks of $-\mathrm{C}-\mathrm{O}-$ stretching were observed in the fingerprint region of the starch spectrum. The peak at $1152 \mathrm{~cm}^{-1}$ is associated with the $\mathrm{C}-\mathrm{O}$ bond stretching of the $\mathrm{C}-\mathrm{O}-\mathrm{H}$ groups, and the peaks at 1080 and $1027 \mathrm{~cm}^{-1}$ are attributed to covalent bond stretching of the $\mathrm{C}-\mathrm{O}-\mathrm{C}$ group in the anhydroglucose ring [22]. 
In the case of the sodium alginate spectrum, the band located between 3692 and $2974 \mathrm{~cm}^{-1}$ was associated with the $-\mathrm{O}-\mathrm{H}$ and $\mathrm{C}-\mathrm{H}$ aliphatic chain stretching vibrations, respectively [23]. The signal observed at $1597 \mathrm{~cm}^{-1}$ corresponds to the asymmetric stretching vibration of the carbonyl bond $-\mathrm{C}=\mathrm{O}$, while that peaks of 1411 and $1025 \mathrm{~cm}^{-1}$ are attributed to carboxyl stretching (-COO and $-\mathrm{C}-\mathrm{O})$.

The observed spectrum for collagen is similar to that reported for buffalo skin [24]. The band located between 3684 and $3113 \mathrm{~cm}^{-1}$ is attributed to the $\mathrm{N}-\mathrm{H}$ stretching vibration of Amide A, $1635 \mathrm{~cm}^{-1}$ (primary amide), which is associated with stretching vibrations of carbonyl groups ( $\mathrm{C}=\mathrm{O}$ bond) along the polypeptide backbone, and the $1529 \mathrm{~cm}^{-1}$ (secondary amide) signal results from $\mathrm{N}-\mathrm{H}$ bending vibration, coupled with the stretching vibration of C-N. The signal at $1243 \mathrm{~cm}^{-1}$ (tertiary amide) is associated with $\mathrm{C}-\mathrm{N}$ stretching, and the NH peak is related with the triple helix structure of collagen.

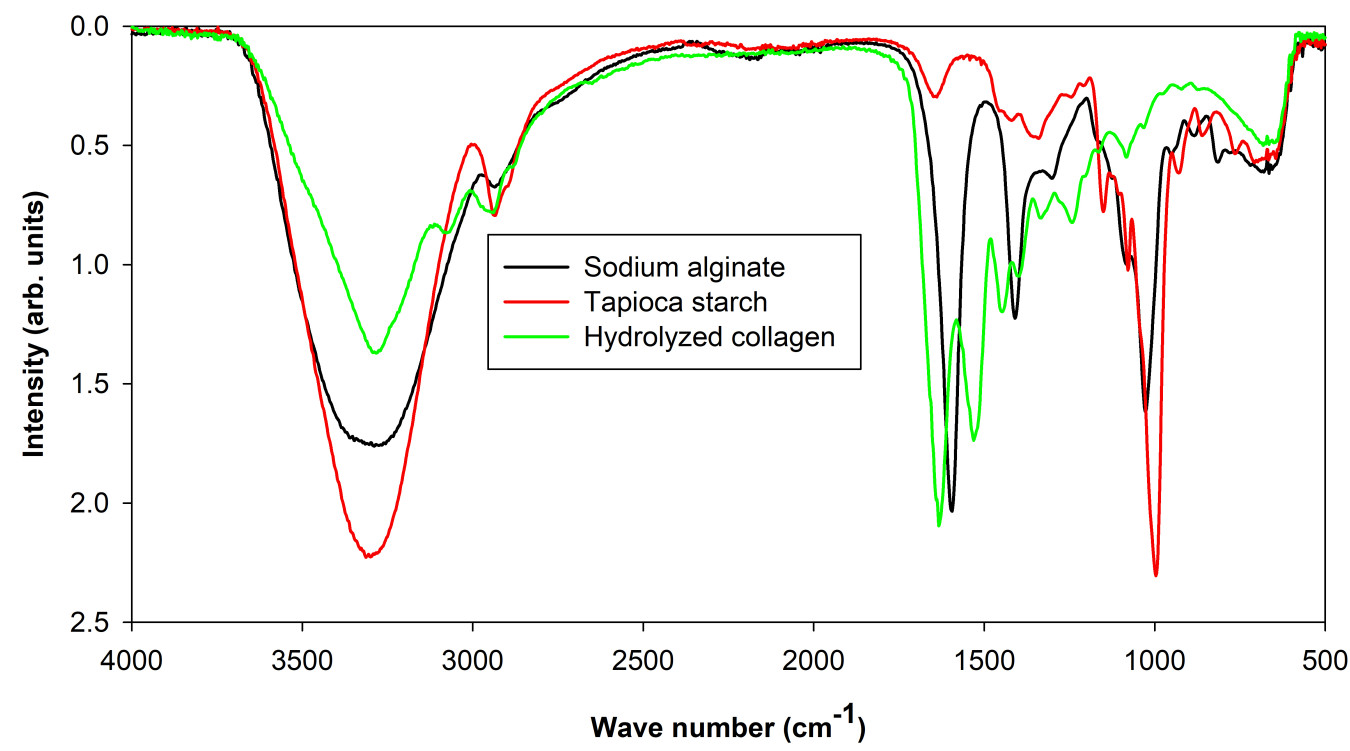

Figure 1. FTIR spectra of film-forming materials: sodium alginate(_), tapioca starch (_), hydrolyzed collagen (-).

Figure 2 depicts the spectra of the CA-S, CA-G, and StA-G biopolymeric films. The FTIR spectra show that the CA-S and CA-G films showed similar patterns, except for a peak observed at $1078 \mathrm{~cm}^{-1}$ in the sorbitol plasticized film (CA-S). This new band at $1078 \mathrm{~cm}^{-1}$ (see arrow in Figure 2) is attributed to $\mathrm{C}-\mathrm{O}-\mathrm{H}$ bending from interactions between sorbitol and polymers.

Concerning the StA-G film, spectra showed bands corresponding to starch, sodium alginate, and glycerol; a strong signal was observed at $1025 \mathrm{~cm}^{-1}$ assigned to $-\mathrm{C}-\mathrm{O}$ groups (Figure 2). This suggests that hydroxyl and carboxylate groups from sodium alginate and tapioca starch form a very strong intramolecular hydrogen bonding with glycerol. In the spectra of sodium alginate, the bands at 1597 and $1411 \mathrm{~cm}^{-1}$ were displaced to 1610 and $1413 \mathrm{~cm}^{-1}$, respectively. The observed change at a higher wave number value shows a reduction in bond strength and stretch frequency. The band associated with stretching vibrations (3692 and $2974 \mathrm{~cm}^{-1}$ ) of sodium alginate was reduced in the StA-G sample (3671 and $2997 \mathrm{~cm}^{-1}$ ). The observed changes suggest intermolecular attraction through the formation of hydrogen bonds between groups in sodium alginate $\left(-\mathrm{COO}^{-}\right)$and groups in tapioca starch $(-\mathrm{OH})$.

\subsection{Thermal Analysis by DSC}

The thermal analysis plays an important role in determining the thermal stability and mechanical performance of films. Figure 3 shows the $T_{g}$ of the biopolymeric films manufactured by the casting process, and Figure 4 shows the $T_{g}$ of film-forming poly- 
mers. The CA-S film showed a $T_{g}=-24.94{ }^{\circ} \mathrm{C} \pm 1.19$ with a $\Delta C_{p}=0.88 \pm 0.05 \mathrm{~J} /\left(\mathrm{g} \cdot{ }^{\circ} \mathrm{C}\right)$, and $T_{g}=40.84 \pm 0.48{ }^{\circ} \mathrm{C}$ with a $\Delta C_{p}=0.16 \pm 0.01 \mathrm{~J} /\left(\mathrm{g} \cdot{ }^{\circ} \mathrm{C}\right)$. The CA-G film showed a $T_{g}=-21.83 \pm 1.08{ }^{\circ} \mathrm{C}$ with a $\Delta C_{p}=0.19 \pm 0.03 \mathrm{~J} /\left(\mathrm{g} \cdot{ }^{\circ} \mathrm{C}\right)$, and a $T_{g}=33.70 \pm 1.60$ with a $\Delta C_{p}=0.13 \pm 0.03 \mathrm{~J} /\left(\mathrm{g} \cdot{ }^{\circ} \mathrm{C}\right)$. The high degree of crosslinking between hydrolyzed collagen and sodium alginate in the CA-S and CA-G films, together with the plasticizer during film formation showed a decrease in the first $T_{g}$ with respect to the $T_{g}$ of collagen anhydrous $\left(82.51 \pm 0.21^{\circ} \mathrm{C}\right.$ ), and a second $T_{g}$ allied to the $T_{g}$ of sodium alginate anhydrous $\left(41.85 \pm 1.47^{\circ} \mathrm{C}\right)$. Sodium alginate presented the following melting parameters: $T_{0}=145.75 \pm 0.01, T_{p}=145.84 \pm 0.07, T_{c}=152.67 \pm 0.4{ }^{\circ} \mathrm{C}$, and $\Delta H=7.09 \mathrm{~J} / \mathrm{g} \pm 0.14$, which are lower than those obtained for the CA-S and CA-G films, except for enthalpy of fusion. These results show a greater thermal stability of the films containing both polymers than sodium alginate itself. In a previous work [10], it was reported that the addition of sodium alginate to collagen films increased the polymeric interactions in the films. Regarding the CA-S and CA-G films (see zoomed plot in Figure 3), remarkable differences in thermal properties were observed with the type of plasticizer used; the CA-G film melted at a higher temperature than CA-S, and CA-S showed the highest melting enthalpy.

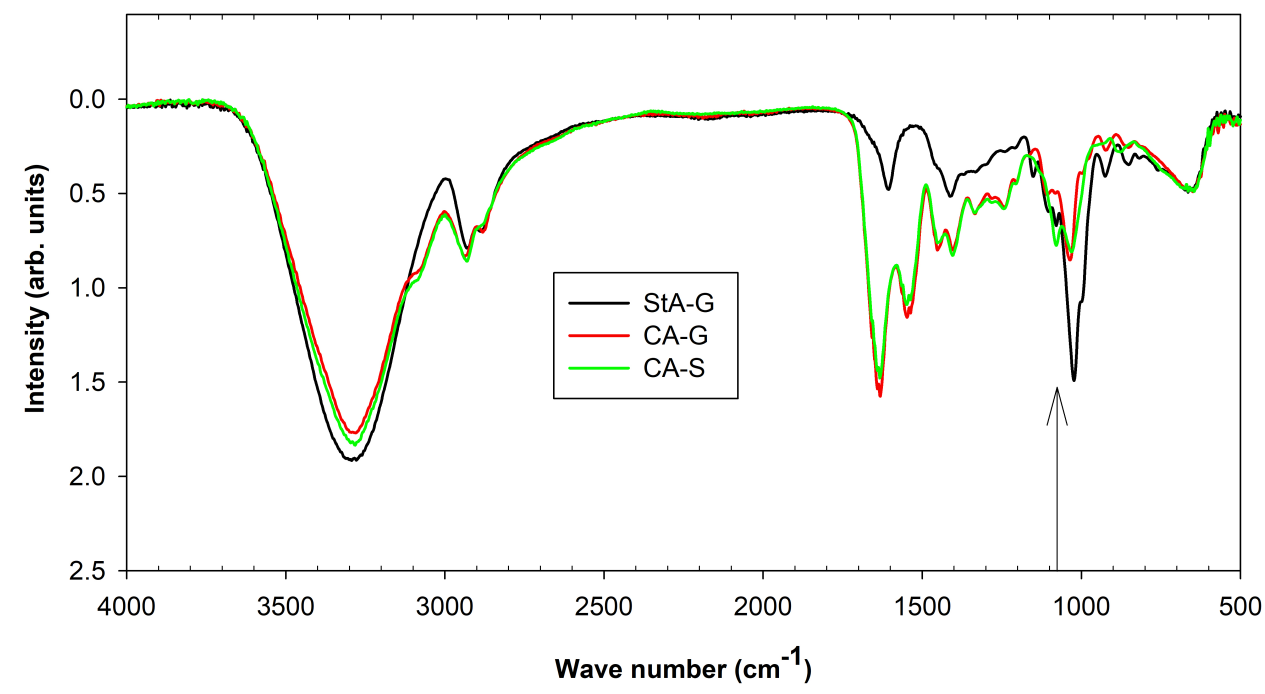

Figure 2. FTIR spectra of biofilms: StA-G (-), CA-G (-), and CA-S (-). The arrow indicates a new peak at $1078 \mathrm{~cm}^{-1}$ in the CA-S sample.

In the StA-G sample, the $T_{g}$ could not be detected during the DSC experiment (see Figure 3). Sodium alginate is a polysaccharide polymer, which contains two hydroxyl $(\mathrm{OH}-)$ segments and one carboxylate $\left(-\mathrm{COO}^{-}\right)$segment in every repeating unit, and each anhydroglucose unit in starch contains three hydroxyl groups. The tapioca starch sample showed a $T_{g}=53.65 \pm 8.3^{\circ} \mathrm{C}$ (see Figure 4); the starch was completely gelatinized and the enthalpy of fusion of the film was very small at $150{ }^{\circ} \mathrm{C}$. Due to the dynamic range of the DSC we could not observe transitions greater than $160^{\circ} \mathrm{C}$; it has been reported [21] that incorporation of starch into sodium alginate films led to melting temperatures in the range of $219-226^{\circ} \mathrm{C}$.

\subsection{XRD Analysis}

The diffractogram patterns for each biofilm formulation and relative crystallinity are shown in Figure 5. X-ray diffraction patterns of biopolymeric films showed absorption peaks and an amorphous zone. The collagen-alginate films (CA-S, CA-G) showed a higher intensity in XRD peaks at $2 \theta=21^{\circ}$ and $2 \theta=40^{\circ}$ than the starch-alginate-film (StA-G). The diffraction peak at $2 \theta=21^{\circ}$ is related to structural layers of collagen fibrils [25], and the broad peak at $2 \theta=40^{\circ}$ is attributed to sodium alginate [26]. The type of plasticizer lightly affected the XRD pattern of the biofilms; the biofilm plasticized with glycerol showed an 
additional shoulder at $2 \theta=31^{\circ}$, indicating enhancement of the film's crystalline structure. Films plasticized with glycerol showed higher $\mathrm{Cr}$ than those plasticized with sorbitol.

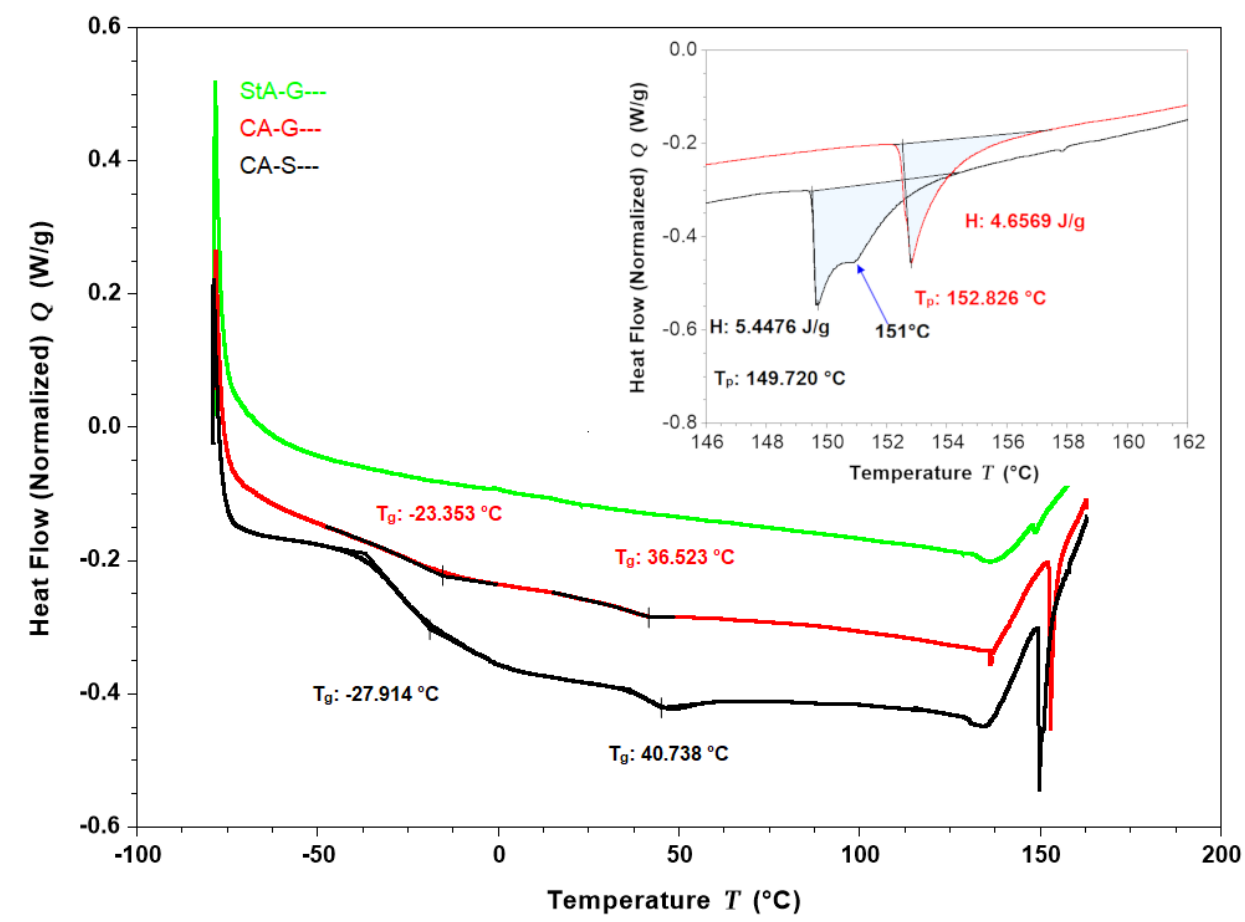

Figure 3. DSC thermograms of casting films: StA-G (-), CA-G (-), and CA-S (-). Zooming in on a portion of the graph showing the melting point of the CA-G and CA-S films.

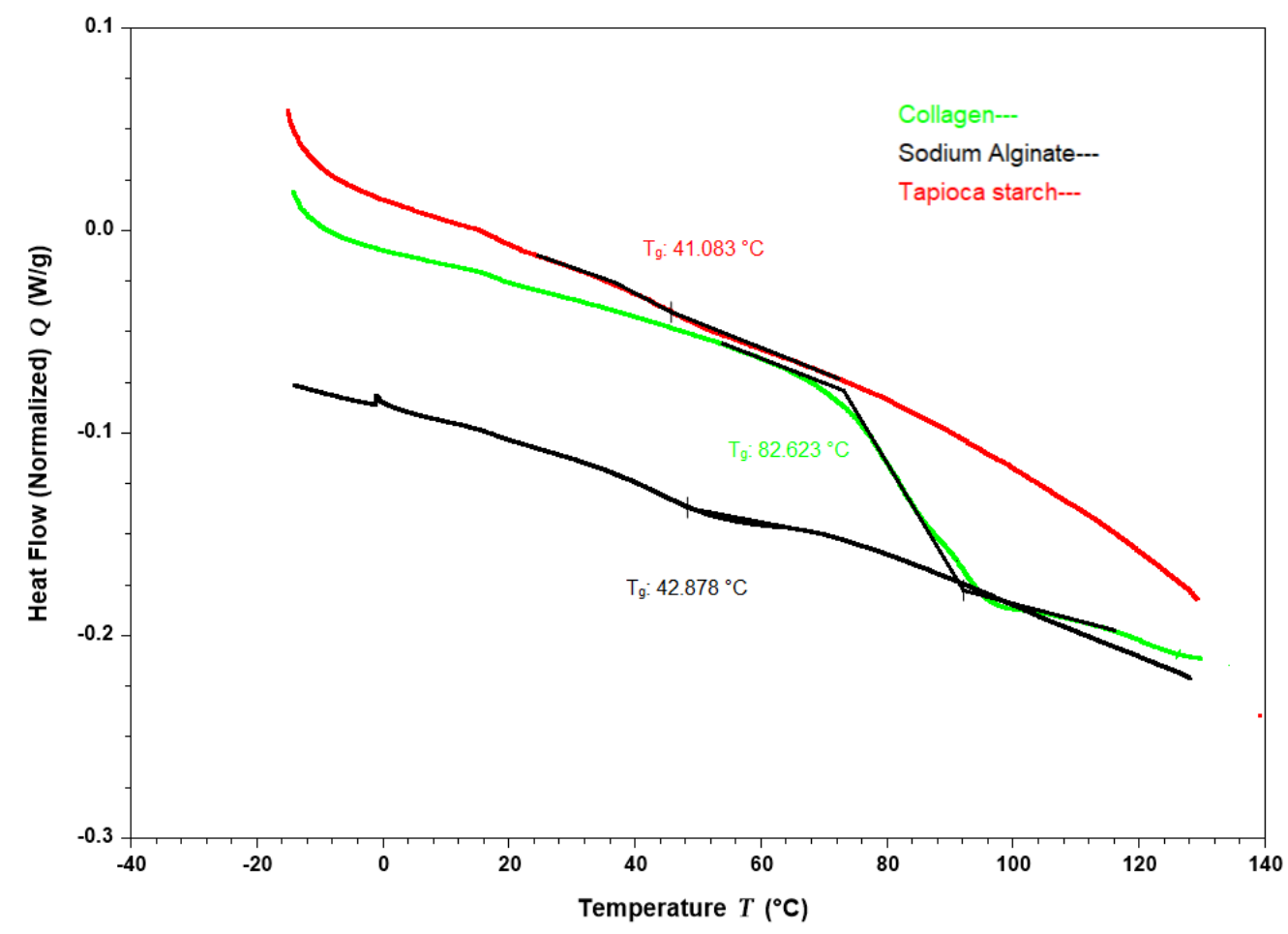

Figure 4. Glass transition of film-forming polymers: collagen (-), sodium alginate (-), and tapioca $\operatorname{starch}(-)$. 


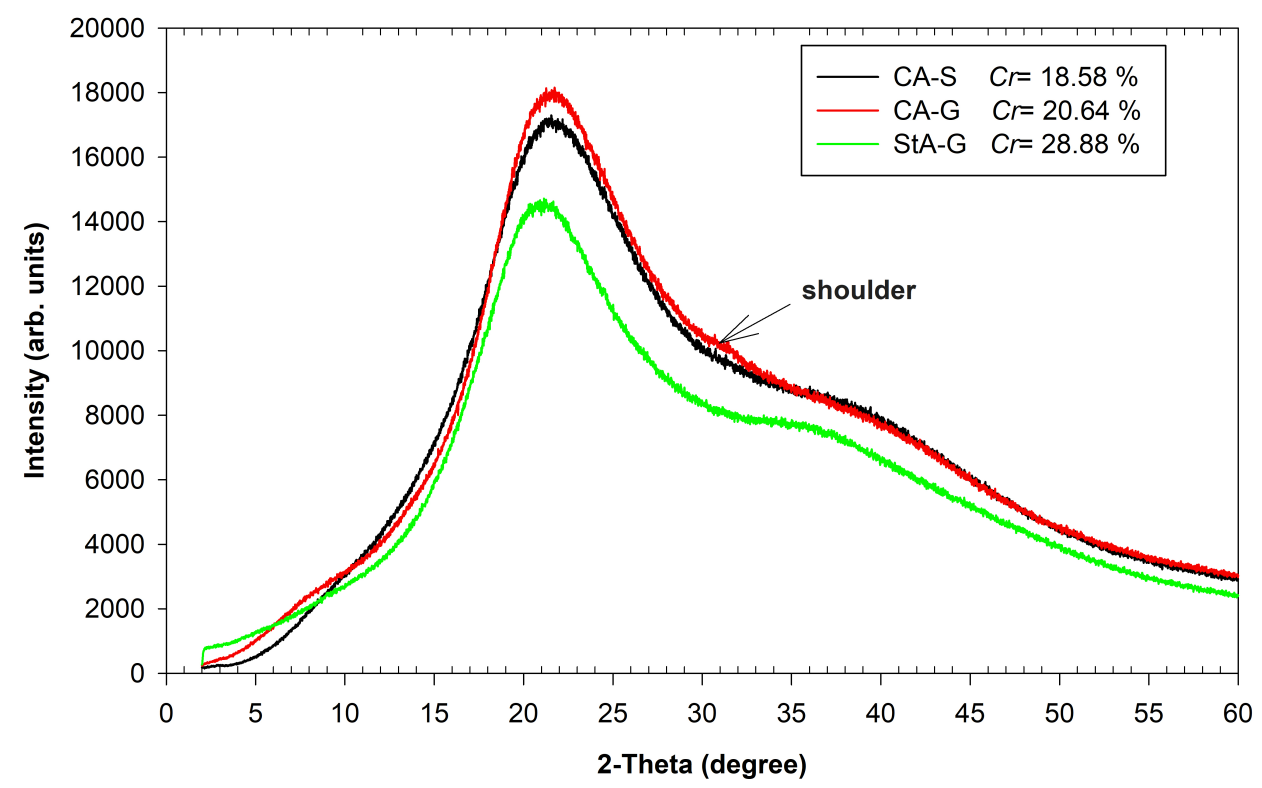

Figure 5. Diffraction patterns and percent crystallinity $(\mathrm{Cr})$ of biopolymeric films: CA-S (_), CA-G (-), StA-G (-). The arrow indicates a shoulder in the CA-G sample

\subsection{Mechanical Properties}

The results regarding the mechanical properties of the prepared biofilms are shown in Table 1. TS represents the maximum strength of a film against applied tensile stress, $E$ represents the ability of a biofilm to stretch, and $Y M$ indicates the rigidity of a film [27]. It should be noted that the starch-sodium alginate biofilm plasticized with sorbitol was not analyzed in this study because the biofilm was brittle, thus inhibiting the analysis. The TS of the collagen-alginate biofilms was highest in the CA-S film plasticized with sorbitol $(4.78 \mathrm{MPa})$ and lowest in CA-G film $(0.96 \mathrm{MPa})$. This could be due to the higher enthalpy needed to break the interaction formed between polymer-sorbitol $(5.446 \mathrm{~J} / \mathrm{g})$ than polymer-glycerol $(4.6569 \mathrm{~J} / \mathrm{g})$.

It was observed that the use of sorbitol in the CA-S film resulted in a stronger network structure than when glycerol was used in CA-G; these results agree with those obtained in FTIR (see Section 2). Similarly, Elango et al. [28], showed that catfish collagen-sorbitol casting films had a higher TS (4.8 MPa) than those obtained for catfish collagen-pglycerol casting films (TS: 4.1 MPa). In a recent work [29], it was shown that sodium alginate can improve the mechanical properties of collagen, which tends to become brittle during storage. This research showed that sodium alginate strengthens the collagen film structure, and therefore we decided to use the sodium alginate-collagen mixture in this research. Comparatively, the performance of protein films against polysaccharide films using glycerol indicated that polysaccharide films (StA-G) have a higher TS than films containing protein (CA-G). These results agree with those of Wang et al. (2017) [13].

StA-G films showed the highest $E(83 \%)$ followed by CA-G glycerol ( $E$ : $73 \%)$ and CA-S (E: $41 \%$ ). The compatibility of glycerol with starch through hydrogen bonding reduced the intramolecular attractions between starch chains, thereby promoting the mobility of the polymer chains in the StA-G film. Although StA-G presented the best $E$, its performance was less than the TS (10 MPa) reported for polyethylene films [30,31]; for this reason a coating with kraft paper [32] is suggested to improve the mechanical properties of the films for its application as packaging material. The $E$ of CA-S was lower than the value obtained for StA-G; however, its therapeutic characteristics suggest that CA-S may have biomedical applications, since collagen and sodium alginate have been widely studied for tissue regeneration [33-35]. 
Table 1. Mechanical properties and viability of B. bacteriovorus HD100 in the biofilms.

\begin{tabular}{lccc}
\hline Analysis & StA-G & CA-G & CA-S \\
\hline Mechanical properties: & & & \\
Thickness $(\mu \mathrm{m})$ & $32.6 \pm 0.03 \mathrm{a}$ & $96.6 \pm 0.16 \mathrm{~b}$ & $37.9 \pm 0.17 \mathrm{a}$ \\
TS (MPa) & $3.166 \pm 0.98 \mathrm{a}$ & $0.965 \pm 0.15 \mathrm{~b}$ & $4.781 \pm 0.89 \mathrm{a}$ \\
E (\%) & $83.25 \pm 8.07 \mathrm{~b}$ & $73.60 \pm 7.96 \mathrm{c}$ & $41.07 \pm 5.23 \mathrm{a}$ \\
YM (MPa) & $0.031 \pm 0.00 \mathrm{~b}$ & $0.021 \pm 0.00 \mathrm{~b}$ & $0.746 \pm 0.18 \mathrm{a}$ \\
Viability of B. bacteriovorus in the films: & & & \\
Cell density (PFU/g) & $2.8 \times 10^{7} \mathrm{c}$ & $2.2 \times 10^{7} \mathrm{~b}$ & $3.0 \times 10^{8} \mathrm{a}$ \\
EY $(\%)$ & 80.58 & 79.28 & 93.46 \\
\hline
\end{tabular}

Different letters $(\mathrm{a}-\mathrm{c})$ within a row indicate significant differences among the films $(p<0.05)$. TS: tensile stress; $E$ : percentage of elongation; $Y M$ : young's modulus; cell density: plaque-forming unit per gram of film; EY: entrapment yield.

\subsection{Visualization of Bdellovibrio bacteriovorus HD100 Strain by SEM}

The micrographs observed by SEM depict the integrity of B. bacteriovorus after its entrapment in biofilms. Figure 6 shows the rod-shaped B. bacteriovorus HD100 strain completely embedded in the film matrix, a single bacteria (Figure 6e), and a clump of bacterial cells that is enclosed in a red circle (Figure $6 \mathrm{f}$ ). The size of the B. bacteriovorus HD 100 strain observed by SEM was approximately $1 \mu \mathrm{m}$ in length, similar to the value of $0.8 \mu \mathrm{m}$ observed for the B. bacteriovorus 109J strain [36]. A cross section of the CA-S film is shown in Figure 6b, where specimens with unaltered morphology were observed. In the micrographs, smoother surfaces were observed in StA-G than in CA-G and CA-S, indicating the higher homogeneity of the StA-G films. Contrarily, CA-S and CA-G showed some bumps in their surface (Figure 6d). These bumps could be attributed to undenatured collagen fibrils, which are between approximately 0.5 and $1 \mu \mathrm{m}$ in length. A study [37] has shown that collagen fibril diameters are between 0.1 and $0.3 \mu \mathrm{m}$.

\subsection{Viability of B. bacteriovorus HD100 in the Biofilms}

Table 1 shows the cell density of B. bacteriovorus HD100 assessed by the number of plaques formed at $72 \mathrm{~h}$ in the plaque, and its $E Y$ in biopolymeric films. The PFUs produced by B. bacteriovorus cells extracted from the films are shown in Figure 7 . The growing inhibition zone is due to the movement of the predator within the soft top agar; this is a prominent feature of predatory bacteria [38]. In the present work, all double layer agar plates exhibited an inhibitory effect against Escherichia coli DH5 $\alpha$ (Figure 7).

A significant variation $(p<0.01)$ in the viability of B. bacteriovorus HD100 was observed in all treatments; CA-S was more effective than CA-G and StA-G in maintaining the viability of the B. bacteriovorus HD100 strain. Therefore, the highest $E Y$ of $93.46 \%$ resulted for the film plasticized with sorbitol (CA-S). This result agrees with the work of Dashiff and Kadouri [39], who showed that high concentrations of glycerol can inhibit the viability of the B. bacteriovorus HD100 strain and predation of the oral pathogens Aggregatibacter actinomycetemcomitans and Eikenella corrodens. In a similar study, Bdellovibrio sp. strain F16 was encapsulated in gelatin microparticles by spray drying [40]. The cell density obtained in the present work for the CA-S film (see Table 1) was higher than the cell density $\left(5.4 \times 10^{7} \mathrm{PFU} / \mathrm{g}\right)$ reported for B. bacteriovorus microcapsules [40] produced by spray drying at $140{ }^{\circ} \mathrm{C}$ (inlet temperature). In the aforementioned study, no encapsulation yield was reported for B. bacteriovorus. 


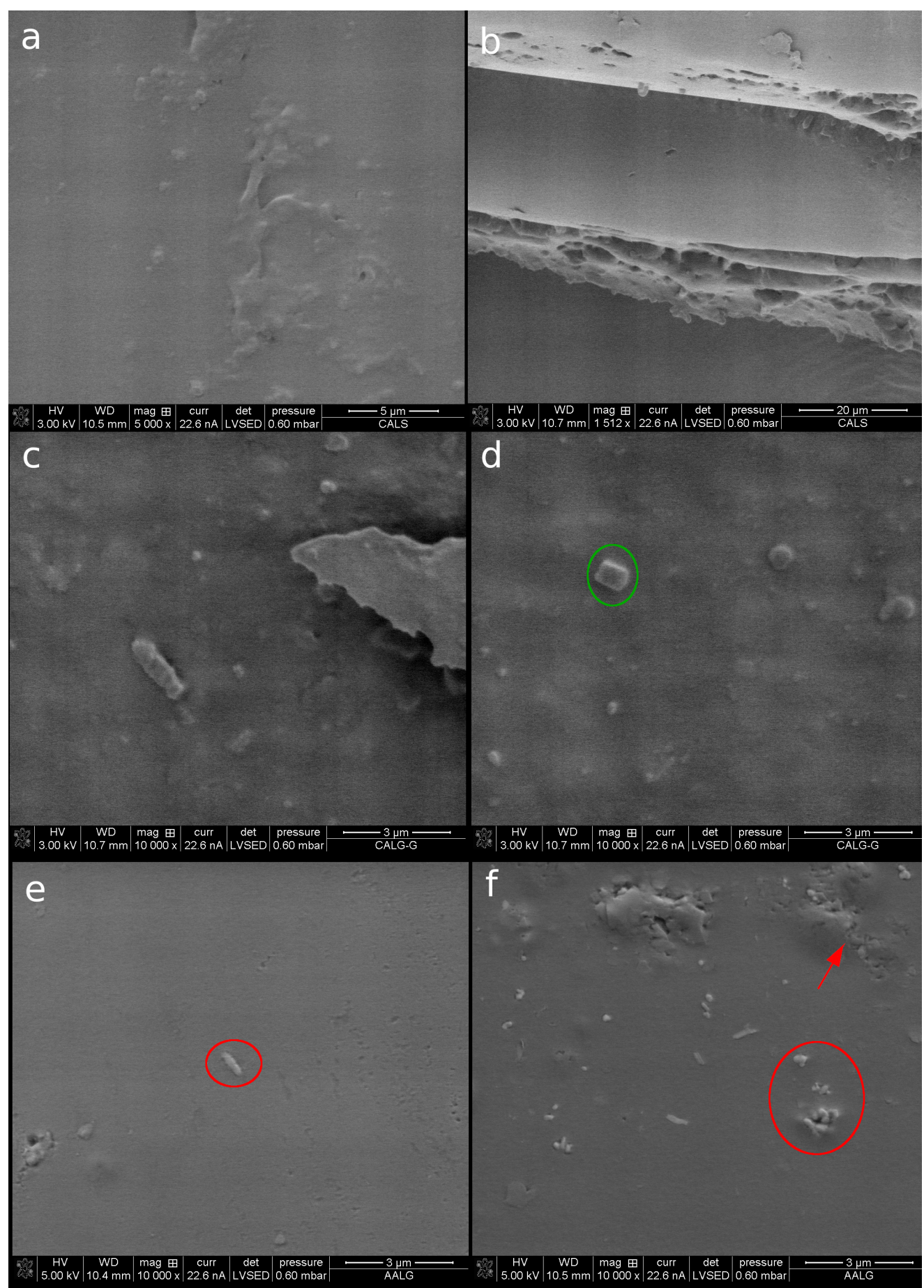

Figure 6. Scanning electron microscopy of B. bacteriovorus HD100 in: (a) CA-S film at 5000 $\times$, and (b) $1512 \times$; (c,d) CA-G film at 10,000×; (e,f) StA-G film at 10,000 $\times$. The red circles enclose B. bacteriovorus, the arrow points to some specimens embedded in the polymeric matrices, and the green circle encloses a prominence attributed to collagen fibrils. 


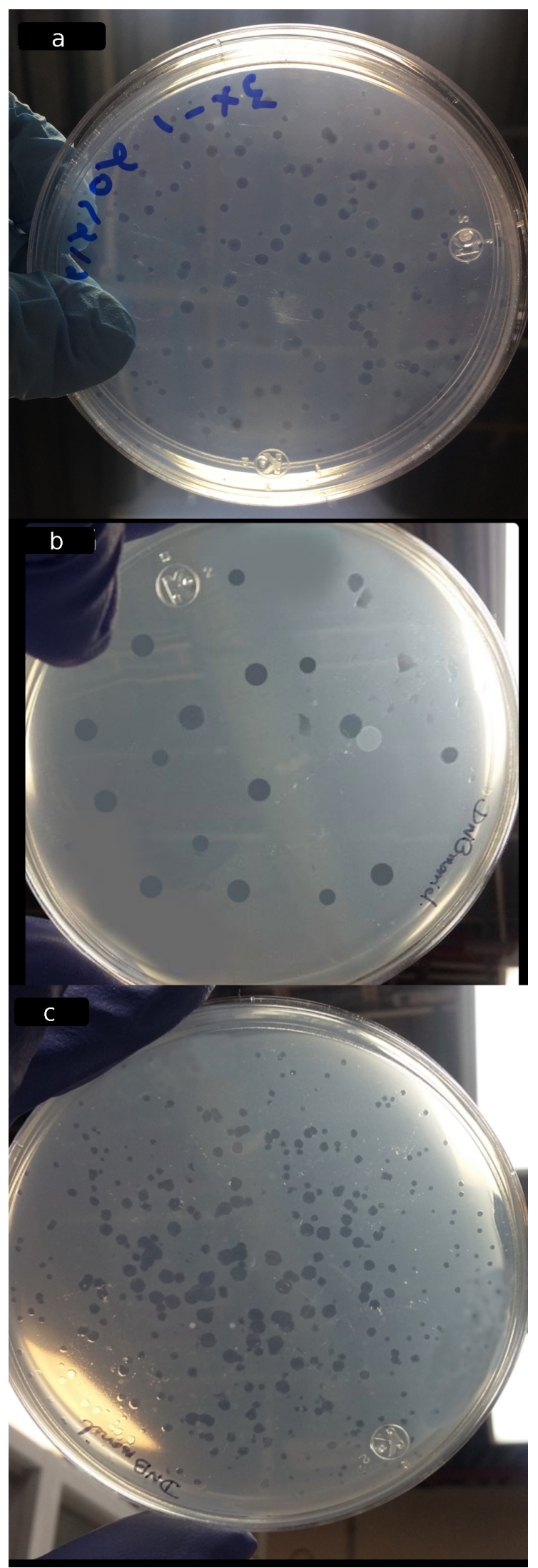

Figure 7. Comparison of lytic plaques developed by B. bacteriovorus HD100 on the lawn of Escherichia coli $\mathrm{DH} 5 \alpha$ prey cells. Inhibition zones are observed in StA-G (a), CA-G (b), and CA-S (c) plaques. 
The concentration of $E$. coli bacterial cells (CFU $/ \mathrm{mL}$ ) obtained after $48 \mathrm{~h}$ upon exposure to the predator in HEPES buffer is shown in Figure 8. A decrease in cell concentration was observed compared to the initial inoculum $(p<0.05)$, and after $48 \mathrm{~h}$ the concentration of E. coli decreased by 1.42 logs. The results presented in this test confirm that active films have potential application in food preservation in forthcoming work.

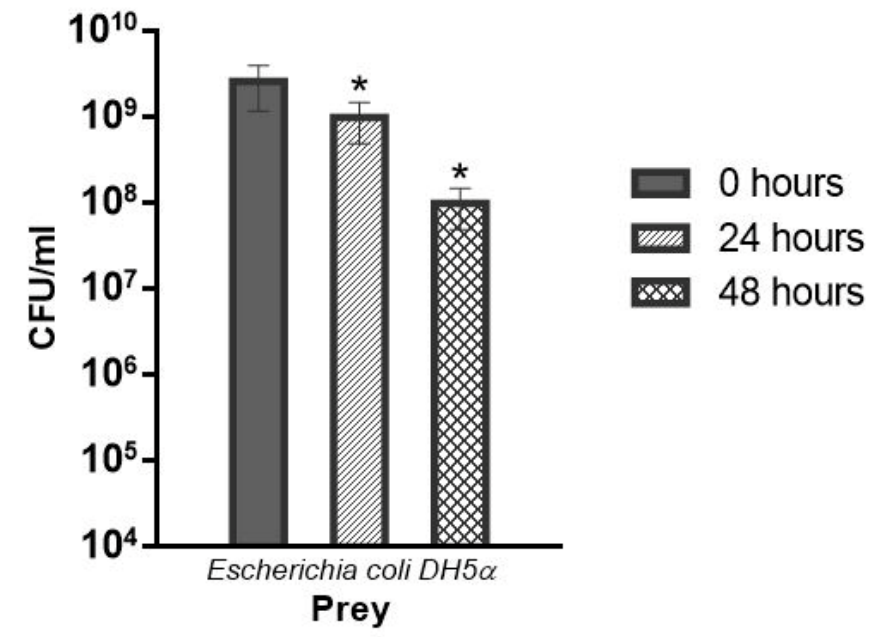

Figure 8. Viability of Escherichia coli $\mathrm{DH} 5 \alpha(\mathrm{CFU} / \mathrm{mL})$ in co-cultivation with Bdellovibrio bacteriovorus HD100. * The cell counts were significantly reduced $(p<0.05)$ after 24 and $48 \mathrm{~h}$.

\section{Conclusions}

To the best of our knowledge, this was the first time in which B. bacteriovorus HD100 strain was trapped into three different biopolymeric films by a casting process. The best suitable biopolymer formulation for the entrapment of the B. bacteriovorus HD100 strain was CA-S, which protected and enhanced the survival of B. bacteriovorus HD100 compared to CA-G and StA-G.

The CA-S film showed the highest TS, as was supported by FTIR analysis. It showed new chemical interactions between sorbitol and biopolymers. Moreover, the CA-S film had the highest TS, and required the highest melting enthalpy.

$B$. bacteriovorus showed effective predatory activity against Escherichia coli $\mathrm{DH} 5 \alpha$; thus, biopolymeric films containing the B. bacteriovorus HD100 strain can be used as biocontrol agents against pathogens in packaging materials to increase the shelf life of food products, for instance.

Author Contributions: Conceptualization, M.A.R.-P. and Y.V.G.-T.; Formal analysis, M.A.R.-P., E.V. and Y.V.G.-T.; Investigation, M.A.R.-P., C.M.S.-S., Y.V.G.-T. and O.O.O.; Methodology, C.M.S.-S., E.V., O.O.O., C.A.R.-B. and Y.V.G.-T.; Resources, M.A.R.-P., E.M.G.-O., Y.V.G.-T. and E.V.; Software, Y.V.G.-T. and C.A.R.-B.; Supervision, M.A.R.-P., E.M.G.-O. and E.V.; Validation, M.A.R.-P., E.M.G.-O., O.O.O., E.V., Y.V.G.-T. and C.A.R.-B.; Writing-original draft, C.M.S.-S., M.A.R.-P., O.O.O. and Y.V.G.-T. All authors have read and agreed to the published version of the manuscript.

Funding: This research was funded by SIP project 20211607 (Y.V.G.-T.).

Institutional Review Board Statement: Not applicable.

Informed Consent Statement: Not applicable.

Data Availability Statement: The data used to support the findings of this study are available from the corresponding author upon request.

Acknowledgments: The authors acknowledge the experimental support of the CNMN-IPN in the realization of the present work.

Conflicts of Interest: The authors declare no conflict of interest. 


\begin{abstract}
Abbreviations
CA-S collagen-sodium alginate film plasticized with sorbitol

CA-G collagen-sodium alginate film plasticized with glycerol

StA-G tapioca starch-sodium alginate film plasticized with glycerol

EY entrapment yield
\end{abstract}

\title{
References
}

1. Kumar, S.; Mukherjee, A.; Dutta, J. Chitosan Based Nanocomposite Films and Coatings: Emerging Antimicrobial Food Packaging Alternatives. Trends Food Sci. Technol. 2020, 97, 196-209. [CrossRef]

2. Li, C.; Pei, J.; Xiong, X.; Xue, F. Encapsulation of Grapefruit Essential Oil in Emulsion-Based Edible Film Prepared by Plum (Pruni Domesticae Semen) Seed Protein Isolate and Gum Acacia Conjugates. Coatings 2020, 10, 784. [CrossRef]

3. Morales, P.; Aguirre, J.; Troncoso, M.; Figueroa, G. Comparison of in Vitro and in Situ Antagonism Assays as Tools for the Selection of Bio-Preservative Lactic Acid Bacteria (LAB) in Poultry Meat. LWT 2020, 118, 108846. [CrossRef]

4. Shaikh, S.M.; Doijad, R.C.; Shete, A.S.; Sankpal, P.S. A Review on: Preservatives used in Pharmaceuticals and impacts on Health. Pharma Tutor 2016, 4, 25-34

5. Thomashow, M.F.; Cotter, T.W. Bdellovibrio Host Dependence: The Search for Signal Molecules and Genes that Regulate the Intraperiplasmic Growth Cycle. J. Bacteriol. 1992, 174, 5767. [CrossRef] [PubMed]

6. Engelking, H.M.; Seidler, R.J. The Involvement of Extracellular Enzymes in the Metabolism ofBdellovibrio. Arch. Microbiol. 1974, 95, 293-304. [CrossRef] [PubMed]

7. Iebba, V.; Santangelo, F.; Totino V.; Nicoletti M.; Gagliardi A.; De Biase R.V. Higher Prevalence and Abundance of Bdellovibrio bacteriovorus in the Human Gut of Healthy Subjects. PLoS ONE 2013, 8, e61608. [CrossRef]

8. Bonfiglio, G.; Neroni, B.; Radocchia, G.; Marazzato, M.; Pantanella, F.; Schippa, S. Insight into the Possible Use of the Predator Bdellovibrio bacteriovorus as a Probiotic. Nutrients 2020, 12, 2252. [CrossRef]

9. Hong, H.; Fan, H.; Chalamaiah, M.; Wu, J. Preparation of Low-Molecular-Weight, Collagen Hydrolysates (Peptides): Current Progress, Challenges, and Future Perspectives. Food Chem. 2019, 301, 125222. [CrossRef] [PubMed]

10. Shi, D.; Liu, F.; Yu, Z.; Chang, B.; Goff, H.D.; Zhong, F. Effect of Aging Treatment on the Physicochemical Properties of Collagen Films. Food Hydrocoll. 2019, 87, 436-447. [CrossRef]

11. Chen, X.; Zhou, L.; Xu, H.; Yamamoto, M.; Shinoda, M.; Tada, I.; Minami, S.; Urayama, K.; Yamane, H. The Structure and Properties of Natural Sheep Casing and Artificial Films Prepared from Natural Collagen with various Crosslinking Treatments. Int. J. Biol. Macromol. 2019, 135, 959-968. [CrossRef]

12. Bhuimbar, M.V.; Bhagwat, P.K.; Dandge, P.B. Extraction and Characterization of Acid Soluble Collagen from Fish Waste: Development of Collagen-Chitosan Blend as Food Packaging Film. J. Environ. Chem. Eng. 2019, 7, 102983. [CrossRef]

13. Wang, Z.; Hu, S.; Wang, H. Scale-Up Preparation and Characterization of Collagen/Sodium Alginate Blend Films. J. Food Qual. 2017, 2017, 4954259. [CrossRef]

14. Santacruz, S.; Castro, M. Viability of Free and Encapsulated Lactobacillus Acidophilus Incorporated to Cassava Starch Edible Films and its Application to Manaba Fresh White Cheese. LWT 2018, 93, 570-572. [CrossRef]

15. Oyedara, O.O.; De Luna-Santillana, E.J.; Olguin-Rodriguez, O.; Guo, X.; Mendoza-Villa, M.; Menchaca-Arredondo, J.; Elufisan, T.O.; Garza-Hernandez, J.; Garcia Leon, I.; Rodriguez-Perez, M. Isolation of Bdellovibrio Sp. from Soil Samples in Mexico and their Potential Applications in Control of Pathogens. Microbiologyopen 2016, 5, 992-1002. [CrossRef] [PubMed]

16. Dong, H.; Hou, H.; Liu, C.; Zhang, H. Relationships between some Physicochemical Properties of Starches from Maize Cultivars Grown in East China. Starch-Stärke 2008, 60, 305-314. [CrossRef]

17. García-Tejeda, Y.V.; Leal-Castañeda, E.J.; Espinosa-Solis, V.; Barrera-Figueroa, V. Synthesis and Characterization of Rice Starch Laurate as Food-Grade Emulsifier for Canola Oil-in-Water Emulsions. Carbohydr. Polym. 2018, 194, 177-183. [CrossRef]

18. Romero-Bastida, C.A.; Bello-Pérez, L.A.; Velazquez, G.; Alvarez-Ramirez, J. Effect of the Addition Order and Amylose Content on Mechanical, Barrier and Structural Properties of Films made with Starch and Montmorillonite. Carbohydr. Polym. 2015, 127, 195-201. [CrossRef] [PubMed]

19. García-Tejeda, Y.V.; Salinas-Moreno, Y.; Hernández-Martínez, Á.R.; Martínez-Bustos, F. Encapsulation of Purple Maize Anthocyanins in Phosphorylated Starch by Spray Drying. Cereal Chem. 2016, 93, 130-137. [CrossRef]

20. Fazaeli, M.; Emam-Djomeh, Z.; Kalbasi Ashtari, A.; Omid, M. Effect of Spray Drying Conditions and Feed Composition on the Physical Properties of Black Mulberry Juice Powder. Food Bioprod. Process. 2012, 90, 667-675. [CrossRef]

21. Siddaramaiah; Swamy, T.M.M.; Ramaraj, B.; Lee, J.H. Sodium Alginate and its Blends with Starch: Thermal and Morphological Properties. J. Appl. Polym. Sci. 2008, 109, 4075-4081. [CrossRef]

22. Wang, L.; Wang, Y. Structures and Physicochemical Properties of Acid-Thinned Corn, Potato and Rice Starches. Starch-Stärke 2001, 53, 570-576. [CrossRef]

23. Pereira, R.; Tojeira, A.: Vaz, D.C.; Mendes, A.; Bártolo, P. Preparation and characterization of films based on alginate and aloe vera. Int. J. Polym. Anal. Charact. 2011, 16, 449-464. [CrossRef]

24. Rizk, M.A.; Mostafa, N.Y. Extraction and Characterization of Collagen from Buffalo Skin for Biomedical Applications. Orient. J. Chem. 2016, 32, 1601-1609. [CrossRef] 
25. Liao, W.; Guanghua, X.; Li, Y.; Shen, X.R.; Li, C. Comparison of Characteristics and Fibril-Forming Ability of Skin Collagen from Barramundi (Lates Calcarifer) and Tilapia (Oreochromis Niloticus). Int. J. Biol. Macromol. 2018, 107, 549-559. [CrossRef]

26. Abdel Aziz, M.S.; Salama, H.E.; Sabaa, M.W. Biobased alginate/castor Oil Edible Films for Active Food Packaging. LWT 2018, 96, 455-460. [CrossRef]

27. Zhang, R.; Wang, W.; Zhang, H.; Dai, Y.; Dong, H.; Hou, H. Effects of Hydrophobic Agents on the Physicochemical Properties of Edible agar/maltodextrin Films. Food Hydrocoll. 2019, 88, 283-290. [CrossRef]

28. Elango, J.; Bu, Y.; Bin, B.; Geevaretnam, J.; Robinson, J.S.; Wu, W. Effect of Chemical and Biological Cross-Linkers on Mechanical and Functional Properties of Shark Catfish Skin Collagen Films. Food Biosci. 2017, 17, 42-51. [CrossRef]

29. Xie Z.; He M.; Zhai Y.; Xin F.; Yu S.; Zhao H.; Xiao H.; Song Y. Preparation of Collagen Casings with High Mechanical Properties using Response Surface Methodology. Am. J. Biochem. Biotechnol. 2021, 17, 1-15. [CrossRef]

30. Otàlora Gonzàlez, C.M.; Flores, S.K.; Basanta, M.F.; Gerschenson, L.N. Effect of Beetroot (Beta Vulgaris L. Var Conditiva) Fiber Filler and Corona Treatment on Cassava Starch Films Properties. Food Packag. Shelf Life 2020, 26, 100605. [CrossRef]

31. Markovicová, L.; Zatkalíková, V.; Kojnoková, T.; Gana, D.; Liptáková, T. The physical - mechanical properties of low-density polyethylene films. IOP Conf. Ser. Mater. Sci. Eng. 2020, 726, 012008. [CrossRef]

32. Nurul Syahida, S.; Ismail-Fitry, M.R.; Ainun, Z.M.A.; Nur Hanani, Z.A. Effects of gelatin/palm wax/lemongrass Essential Oil (GPL)-Coated Kraft Paper on the Quality and Shelf Life of Ground Beef Stored at $4{ }^{\circ}$ C. Food Packag. Shelf Life 2021, $28,100640$. [CrossRef]

33. Zhang, H.; Peng, M.; Cheng, T.; Zhao, P.; Qiu, L.; Zhou, J.; Lu, G.; Chen, J. Silver Nanoparticles-Doped collagen-alginate Antimicrobial Biocomposite as Potential Wound Dressing. J. Mater. Sci. 2018, 53, 14944-14952. [CrossRef]

34. Zarate-Triviño, D.G.; Pool, H.; Vergara-Castañeda, H.; Elizalde-Peña, E.A.; Vallejo-Becerra, V.; Villaseñor, F.; Prokhorov, E.; Gough, J.; Garcia-Gaitan, B.; Luna-Barcenas, G. (Chitosan-g-Glycidyl Methacrylate)-Collagen II Scaffold for Cartilage Regeneration. Int. J. Polym. Mater. Polym. Biomater. 2020, 69, 1043-1053. [CrossRef]

35. Lee, H.; Ahn, S.; Kim, G.H. Three-Dimensional Collagen/Alginate Hybrid Scaffolds Functionalized with a Drug Delivery System (DDS) for Bone Tissue Regeneration. Chem. Mater. 2012, 24, 881-891. [CrossRef]

36. Núñez, M.E.; Martin, M.O.; Duong, L.K.; Ly, E.; Spain, E.M. Investigations into the Life Cycle of the Bacterial Predator Bdellovibrio Bacteriovorus 109J at an Interface by Atomic Force Microscopy. Biophys. J. 2003, 84, 3379-3388. [CrossRef]

37. Siadat, S.M.; Silverman, A.A.; DiMarzio, C.A.; Ruberti, J.W. Measuring Collagen Fibril Diameter with Differential Interference Contrast Microscopy. J. Struct. Biol. 2021, 213, 107697. [CrossRef]

38. Stolp, H.; Starr, M.P. Bdellovibrio Bacteriovorus Gen. Et Sp. n., a Predatory, Ectoparasitic, and Bacteriolytic Microorganism. Antonie Leeuwenhoek 1963, 29, 217-248. [CrossRef]

39. Dashiff, A.; Kadouri, D.E. Predation of Oral Pathogens by Bdellovibrio Bacteriovorus 109J. Mol. Oral Microbiol. 2011, 26, 19-34. [CrossRef]

40. Cao, H.; Wang, H.; Yu, J.; An, J.; Chen, J. Encapsulated Bdellovibrio Powder as a Potential Bio-Disinfectant Against Whiteleg Shrimp-Pathogenic Vibrios. Microorganisms 2019, 7, 244. [CrossRef] 